\title{
ALCOHOL POLICIES AND \\ HIGHWAY VEHICLE FATALITIES
}

Christopher J. Ruhm

Working Paper No. 5195

\section{NATIONAL BUREAU OF ECONOMIC RESEARCH 1050 Massachusetts Avenue \\ Cambridge, MA 02138 \\ July 1995}

I thank Frank Chaloupka, Michael Grossman, Henry Saffer, and Frank Sloan for helpful comments on an earlier version of this manuscript. Financial support from the National Institute on Alcohol Abuse and Alcoholism (grant no. AA09268-01A1) is gratefully acknowledged. All opinions and errors are my own. This paper is part of NBER's research program in Health Economics. Any opinions expressed are those of the author and not those of the National Bureau of Economic Research.

() 1995 by Christopher J. Ruhm. All rights reserved. Short sections of text, not to exceed two paragraphs, may be quoted without explicit permission provided that full credit, including $\odot$ notice, is given to the source. 


\title{
ALCOHOL POLICIES AND \\ HIGHWAY VEHICLE FATALITIES
}

\begin{abstract}
This study investigates the impact of beer taxes and a variety of alcohol-control policies on motor vehicle fatality rates, using fixed-effect models with data for the $\mathbf{4 8}$ contiguous states over the 1982 through 1988 time period. The econometric findings highlight the fragility of the parameter estimates to reasonable changes in model specifications. Special attention is paid to omitted variables biases resulting from failing to adequately control for grassroots efforts to reduce drunk driving, the enactment of other laws which simultaneously operate to reduce highway fatalities, and the economic conditions existing at the time of the legislation. In the preferred specifications, most of the regulations have little or no impact on traffic mortality. By contrast, higher beer taxes are associated with reductions in crash deaths and this result is relatively robust across specifications. These findings suggest the limited ability of further regulatory action to reduce drunk-driving but point to a potentially significant role for higher alcohol taxes.
\end{abstract}

Christopher J. Ruhm Department of Economics University of North Carolina, Greensboro Greensboro, NC 27412-5001 and NBER 


\section{Alcohol Policies and Highway Vehicle Fatalities}

Traffic fatalities are a major source of accident deaths at all ages and the leading cause of mortality for persons under 40 . Almost half of drivers and more than $40 \%$ of passengers killed in vehicle crashes have been drinking (Zobeck, et. al. 1993), with still higher levels of alcohol-involvement for fatal accidents occurring at night. During the last 15 years, federal and state governments have undertaken unprecedented efforts to reduce this death toll by passing strict regulations aimed at reducing alcohol-involved driving. For instance, the federal Alcohol Traffic Safety Act of 1983 provided incentives for states to enact stringent drunk-driving laws and the Uniform Drinking Act of 1984 included provisions for withholding a portion of federal highway funds from any states failing to raise their minimum legal drinking age (MLDA) to 21.

By 1988 , all 50 states had mandated a 21 MLDA and many had adopted other alcohol-control measures. During the 1980 s, numerous states authorized police to administer roadside breath tests for alcohol, enacted administrative per se laws, requiring license suspension or revocation if a driver's blood alcohol content (BAC) exceeded a prespecified level, mandated minimum jail sentences or community service for driving-under-the influence (DUI), authorized lawsuits against alcohol servers (dram shop laws), required license sanctions for drivers refusing to submit to alcohol testing (implied consent laws), and prohibited open containers of alcohol in the passenger sections of motor vehicles. ${ }^{1}$

Nor does the regulatory activity show any signs of abating. For instance, between 1990 and 1994, the number of states with illegal per se BAC levels of .08\% (rather than $.10 \%$ or higher) increased from 4 to 12 . By the latter year, 39 states had passed administrative per se laws

1 Between 1981 and 1986, 729 drunk-driving laws were passed by states (Evans, et. al., 1991). 
and 26 had established mandatory fines for the first DUI conviction (U.S. Department of Transportation, $1991 \& 1995)$.

Ironically, the legislative action has been at least partially offset by a decline in real alcohol taxes. Despite evidence from numerous studies showing that lower liquor taxes lead to more drinking and drunk-driving (see Cook \& Moore, 1993a or Grossman et. al., 1993 for reviews of this literature), the federal tax rate on beer and wine remained fixed, in nominal terms, between 1951 and 1991 and so fell by four-fifths, over the period, after accounting for inflation (Grossman, et. al., 1993). ${ }^{2}$ Similarly, real state liquor taxes declined more than $50 \%$ between 1966 and $1993 .^{3}$

Although traffic fatalities decreased from 51,077 in 1980 to 44,529 in 1990 (Zobeck, et. al. 1993), there are at least two reasons to doubt that the entire reduction is due to stricter alcohol-control regulations. First, the legislation was accompanied by substantial grassroots activities to change public attitudes towards drinking and driving. For example, Mothers Against Drunk Driving (MADD) formed its first chapter in 1981 and by 1986 had established 395 chapters (Evans, et. al., 1991). These community efforts played a contributory role in reducing highway accidents. Second, the percentage of traffic deaths involving drinking did not fall significantly over the time period, suggesting that driving may have become less risky for reasons unrelated to the prevalence of alcohol (e.g. the establishment of mandatory seat belt laws and the increased availability of vehicle safety features such as anti-lock brakes and air bags). ${ }^{4}$

2 The federal tax was doubled in 1991 but has not been raised since that time and remains low, in real terms, by historical standards. The terms liquor and alcohol are used synonymously throughout this paper to indicate beer, wine, or distilled spirits.

3 This calculation uses data on average nominal tax rates from the U.S. Brewers' Association (1994), deflated by the all-items CPI.

4 Zobeck, et. al. (1993) indicate that $41 \%$ of crash fatalities were alcohol-related in both 1980 and 1990. 
This investigation provides new evidence concerning the effects of alcohol policies on highway vehicle fatalities. Special attention is paid to the fragility of the estimates to plausible changes in model specifications. The predicted effects of anti-drunk-driving legislation appear to be quite sensitive to the inclusion of covariates expected to affect traffic deaths but which have frequently been omitted from earlier analyses. In particular, the estimated regulatory impacts appear to be overstated when changes in public attitudes or in other policies, which simultaneously operate to reduce drunk-driving, are not accounted for and are further reduced by the addition of controls for state level macroeconomic conditions. By contrast, the predicted deterrent effect of alcohol taxes is more robust to alternative specifications. Taken together, these findings suggest the limited ability of further legislative action to reduce alcohol-involved driving but point to a potentially significant role for higher liquor taxes.

\section{Previous Research}

Virtually all contemporary studies find a strong negative relationship between legal drinking ages and vehicle fatalities, although the magnitude of the estimated effects varies widely (see table 1). ${ }^{5}$ Thus, the increases in MLDAs, instituted during the 1980s, are believed to explain a substantial portion of the declining trend in traffic deaths and to have an especially large impact on the mortality of 18 to 20 year olds. Alcohol prices and taxes are also negatively and powerfully correlated with crash fatalities, implying that the erosion in real liquor tax rates has, ceteris paribus, increased this source of mortality.

5 Earlier research focused primarily on the reductions in the legal drinking age occurring in 29 states between 1970 and 1975, in contrast to the increases in MLDAs implemented during the late 1970s and 1980s (see Wagenaar, 1981/2 for details on changes in drinking ages during the 1970s). The early studies often contained methodological or sampling problems and reached little consensus on the effects of changing the drinking age. Wagenaar (1993) provides a comprehensive review of the effects of raising the legal drinking age. 
By contrast, there is less consensus on the impact of alcohol-control regulations other than the legal drinking age. Most available evidence suggests that administrative per se and dram shop laws reduce fatalities (Chaloupka, et. al., 1993; Kenkel, 1993a; Sloan, et. al., 1994), although some studies (e.g. Sloan, et. al. forthcoming) obtain inconclusive results. Mandatory jail sentences for DUI are found to have a deterrent effect by Kenkel (1993a), Sloan \& Githens (1994), and Sloan et. al. (1994), but to have no impact by Wilkinson (1987), Chaloupka, et. al. (1993), and Evans, et. al. (1993). Preliminary breath test laws, sobriety checkpoints, anti-plea bargaining statutes, and changes in tort liability laws reduce predicted traffic deaths in one or more studies but are not controlled for or have no effect in many others. As discussed next, most of the estimates suffer from one or more types of omitted variables bias.

Interstate differences in vehicle mortality are likely to be influenced by disparities in difficult to observe characteristics such as road conditions, driving patterns, and social attitudes towards drinking. Many previous studies have ignored this heterogeneity, resulting in biased estimates if the unobserved factors are correlated with cross-state variations in alcohol policies. In their analysis of legal drinking ages, DuMouchel, et. al. (1987) compare fatality rates for 18 to 20 year olds, the group most affected by the legislation, to those experienced by older drivers. This method, which is similar in spirit to the "differences-in-differences" estimates increasingly used by health and labor economists (e.g. Card \& Krueger, 1994; Gruber, 1994), is not applicable to other regulatory policies, which affect all age groups, and may fail to eliminate the heterogeneity bias to the extent that changes in the MLDA influence the vehicle mortality of other age groups (e.g. those who die in crashes caused by 18 to 20 year olds.).

Other researchers (e.g. Saffer \& Grossman, 1987a,b; Chaloupka, et. al., 1993) include controls for an unusually wide set of characteristics. This has the advantage of providing a more 
fully specified model but the measured differences are unlikely to account for all of the important cross-state disparities. Even the particularly rich background information available to researchers using microdata (e.g. Kenkel, 1993a; O'Malley \& Wagenaar, 1991; Sloan \& Githens, 1994) is unlikely to completely eliminate the heterogeneity. The alternative, and I argue preferable, approach used in this paper is to estimate fixed-effect (FE) models. FE estimates exploit within-state variations in the regressors and outcomes and so have the significant advantage of automatically controlling for time-invariant factors which differ across states. ${ }^{6}$

Prior investigations also typically account for only a small set of the relevant alcohol policies. For instance, DuMouchel, et. al. (1987) and O'Malley \& Wagenaar (1991) investigate the impact of MLDAs, without controlling for liquor prices or any other DUI legislation. Even studies modeling the effects of several types of regulations simultaneously (e.g. Evans, et. al., 1991; Chaloupka, et. al. 1993; Kenkel, 1993a; Sloan, et. al., 1994, forthcoming) are unlikely to hold constant all of the important laws. Furthermore, none of the analyses control for community activities, such as those by Mothers Against Drunk Driving, which have increased over time and (presumably) reduced drunk-driving. Although these source of omitted variables bias can not be entirely eliminated, some information on their importance is obtained below by testing the robustness of the estimates to the inclusion of controls for additional types of DUI legislation and to a vector of year effects.

6 Time-varying factors still need to be controlled for. Some researchers (e.g. Saffer \& Grossman, 1987b; Chaloupka, et. al. 1993) question the use of fixed-effect models because of multicollinearity between the alcohol variables and other regressors. Multicollinearity increases the standard errors of the coefficients but the estimates will still be unbiased, in contrast to methods which fail to purge the cross-state heterogeneity. The first alcohol research using fixed-effect models was by Cook \& Tauchen $(1982,1984)$. More recent examples include DuMouchel, et. al. (1987), Saffer \& Grossman (1987b), Saffer \& Chaloupka (1989), Evans, et. al. (1991), and Sloan, et. al. (1994). 
Finally, traffic fatalities fluctuate with economic conditions. Although some of the variation results from the reduction in driving occurring during recessions, crash deaths are also likely to be affected by cyclical changes in the type and amount of alcohol consumed and possibly in driving patterns. ${ }^{7}$ Previous analyses generally fail to adequately control for the macroeconomy. Personal incomes are sometimes held constant (e.g. Saffer \& Grossman, 1987a,b; Sloan \& Githens, 1994; Sloan, et. al., 1994, forthcoming) but only a few studies (Wagenaar \& Maybee, 1986; Saffer \& Chaloupka, 1989; Chaloupka, et. al. 1993; Evans, et. al. 1993, Kenkel, 1993a) have also accounted for differences in unemployment rates. As shown below, it is important to control for both of these factors at the same time.

\section{Data}

The econometric analysis uses data for the 48 contiguous states over the 1982 through 1988 time period. ${ }^{8}$ Additional information beginning in 1975 is incorporated when describing time trends. Three types of traffic deaths are investigated. The total vehicle fatality rate (VFR) provides the most comprehensive measure of fatal highway crashes. The night-time vehicle fatality rate (NVFR), defined to include deaths from accidents occurring between midnight and 3:59 A.M., focuses on crashes which are more likely to involve alcohol. ${ }^{9}$ Finally, the vehicle

7 Evans \& Graham (1988) provide an excellent discussion of these issues. Ruhm (forthcoming) shows that alcohol consumption is procyclical and that the intake of distilled spirits is more sensitive to economic conditions than is that of wine or beer. One explanation is that individuals may shift drinking away from bars and restaurants, during recessions, where alcohol is relatively expensive. If off-premise drinking is less often followed by driving, this will cause traffic mortality to fall during downturns, even after controlling for miles driven.

8 Hawaii, Alaska, and the District of Columbia are excluded.

9 DuMouchel (1987) estimates that two-thirds of those killed between 8:00 P.M. and 5:00 A.M. have BACs of $0.10 \%$ or higher. There is dispute over which fatality outcome should be used when investigating the effects of alcohol policies. Some researchers (e.g. Cook \& Tauchen, 1984; Saffer \& Grossman, 1987b) argue for a comprehensive measure, such as total fatality rates, whereas others (e.g. O'Malley \& Wagenaar, 1991) focus on narrower outcomes. Although a larger percentage of night than total deaths involve alcohol, the number of crashes reduces the 
fatality rate of 18 to 20 year olds is separately broken out, since this age group is most affected by changes in the legal drinking age. ${ }^{10}$ Information on traffic mortality was obtained from the National Highway Traffic Safety Administration's Fatal Accident Reporting System (FARS)."

The minimum legal drinking age refers to purchases of beer with an alcohol content greater than 3.2\%. Data were obtained from Wagenaar (1981/2) and from various issues of the National Highway Traffic Safety Administration's A Digest of State Alcohol-Highway Safety Laws. The tax rate on 24-12 ounce containers of beer (in \$1987) is controlled for using data from the Brewer's Almanac, which is published annually by the U.S. Brewers' Association. ${ }^{12}$ Information on taxes, rather than prices, is used for two reasons. First, the former are directly set by policy-makers, whereas the latter are not. Second, beer taxes are determined relatively independently of liquor demand, whereas prices result from the interaction of the supply and demand. ${ }^{13}$ Thus, beer taxes and alcohol consumption are expected to be inversely related, whereas, quantities and prices will be positively correlated if demand shocks dominate.

Five regulations designed to deter drunk-driving are analyzed, all modeled as dichotomous variables and using data from various issues of $A$ Digest of State Alcohol-Highway Safety Laws. Preliminary breath test laws (BREATH) indicate whether the state has authorized a breath test as establishing probable cause for DUI. Dram shop legislation (DRAM) refers to case precision of the estimates.

${ }^{10}$ Preliminary analysis was also conducted on the NVFR of 18 to 20 year olds and for an extrapolated series estimating the percentage of dead drivers (of all ages) with BACs exceeding $0.05 \%$. Results were similar to those for total fatalities of the corresponding age group.

${ }^{11}$ I thank Frank Chaloupka for providing me with the data used below on vehicle fatality rates, beer taxes, and state alcohol regulations.

${ }^{12}$ Weighted averages are used to reflect changes in state beer taxes or MLDAs occurring during the middle of calendar years.

${ }^{13}$ Beer taxes are highly correlated with tax rates on wine and distilled spirits and, hence, provide a good proxy of overall alcohol taxes. 
law or statutes allowing those injured by intoxicated persons to bring litigation against the alcohol server. Administrative per se regulations (PERSE) show if the state licensing agency is required to suspend or revoke the individual's license after a DUI arrest. Implied consent legislation (CONSENT) indicates whether the state has instituted mandatory license suspension for individuals refusing to submit to alcohol testing. Finally, JAIL refers to legislation mandating jail or community service for the first DUI conviction. These regulations are not assumed to fully capture regulatory efforts to reduce alcohol-involved driving. Instead, they are chosen to provide a reasonably representative selection of the types of policies considered in previous research.

The econometric models also hold constant the percentage of the state's population living in "dry" counties (DRY), the proportion of drivers between 15 and 24 years old (YOUNG), and the average number of miles driven by persons aged 16 and over (VMILES). Each of these factors is likely to influence traffic mortality and may vary within states over time. Data on DRY are from the Brewer's Almanac, those for YOUNG and VMILES from various issues of the Federal Highway Administration publication Highway Statistics.

Per capita incomes and unemployment rates are used as proxies for macroeconomic conditions. Unemployment rates are expected to be negatively correlated with traffic fatalities, since total alcohol consumption and the proportion of drinking occurring in bars and restaurants is likely to fall during downturns. Personal incomes are predicted to be positively related to vehicle deaths, if drinking and risky-driving are normal goods. A consistent (unpublished) series on unemployment rates for the noninstitutionalized civilian population aged 16 and over was provided to me by the U.S. Bureau of Labor Statistics. Data on per capita incomes were obtained from U.S. Department of Commerce $(1989,1990)$. 
Descriptions and sample means of the variables are presented in appendix table A.I and are self-explanatory. Figure 1 displays trends in vehicle fatalities, drinking ages, and beer taxes over the 1975-88 time period. Traffic deaths peaked between 1978 and 1980, depending on the type of mortality, declined dramatically through the early 1980s, and then leveled off. The average legal drinking age was unchanged between 1975 and 1978 and then rose rapidly during the next decade (increasing from 19.6 to 21.0 years between 1978 and 1988), particularly after passage of the Uniform Drinking Act of 1984. Conversely, substantial reductions in real beer taxes occurred during the high inflation years of the late 1970s and early 1980s (the average tax rate declined from $\$ 0.78$ to $\$ 0.53$ per case between 1975 and 1981 ), followed by somewhat smaller decreases subsequently (to $\$ 0.44 /$ case in 1988 ).

Table 2 details trends in alcohol policies during 1982-88, the period of the econometric analysis. Although states occasionally eliminated previously enacted DUI regulations, the number of states with anti-drunk driving laws in force grows over time, for all five types of legislation. The largest increases are observed for administrative per se statutes (rising from 4 to 22 states) and dram shop laws (from 28 to 36 states) respectively.

Macroeconomic conditions represent a potentially important confounding factor when analyzing the effects of alcohol policies. To illustrate this, figure 2 displays annual unemployment rates in states raising their legal drinking age to 21 in 1982, relative to those with a 21 year old MLDA already in place at that time. The two categories have virtually identical rates of joblessness prior to 1980 and after 1985. During the intervening six years, however, the former group of states experienced consistently lower unemployment, implying that relative rates of joblessness were rapidly increasing at the same time that many of them were instituting a 21 year old drinking age. ${ }^{14}$ The rise in relative unemployment decreases highway deaths. Without 
controlling for economic conditions, this reduction is erroneously attributed to the higher drinking age, resulting in an upwards biased estimate of the MLDA effect.

\section{Econometric Estimates}

Most of the econometric estimates are for fixed-effect models of the form:

$$
V_{i t}=\alpha_{t}+X_{i t} \beta+Z_{i t} \gamma+S_{i}+\varepsilon_{i t}
$$

where $V_{j t}$ is a transformation of the vehicle fatality rate for state $i$ at time $t, X$ is a vector of alcohol policy variables, $Z$ includes other (time-varying) covariates, $\alpha$ is a time-specific intercept (a vector of year dummy variables), S a state fixed-effect (a vector of state dummy variables), $\varepsilon$ is the error term, and data cover the period 1982 through 1988. Equations which exclude the state or time effects are also sometimes estimated.

Since vehicle mortality is a rate, restricted to the range zero through one, the equations are estimated as grouped data logit models. The dependent variable is the natural logarithm of the odds ratio; thus, if $v_{i t}$ is the traffic fatality rate, the regressand is $V_{i t}=\ln \left[v_{i t}\left(1-v_{i t}\right)^{-1}\right]$. Since, the error term is heteroscedastic, with variance $\left[v_{i t}\left(1-v_{i t}\right) n_{i t}\right]^{-1}$, for $n$ the state population, estimates are by weighted least squares, with cell weights $\left[\mathrm{v}_{\mathrm{it}}\left(1-\mathrm{v}_{\mathrm{it}}\right) \mathrm{n}_{\mathrm{it}}\right]^{1 / 2}$.

\section{$\underline{3.1 \text { Total Vehicle Fatalities }}$}

Table 3 displays logit coefficients and accompanying $t$ statistics for seven specifications of the total vehicle fatality equation. Absolute values of the estimated elasticities are also shown for the continuous explanatory variables. In addition to beer taxes and legal drinking ages, all of the models include controls for YOUNG, DRY, and VMILES. ${ }^{15}$ State dummy variables are

${ }^{14}$ Similar results are obtained using any period between 1975 and 1982 as the base year, since there was virtually no change in the states with 21 year old MLDAs during this time span.

${ }^{15}$ Fatalities are positively and significantly related to average vehicle miles and the percentage of the population living in dry counties in most specifications. Coefficients on the proportion of 
omitted from column (a), whereas specifications (b) through (f) provide fixed-effect estimates. Models (c) through (f) also include dichotomous variables for the five DUI regulations (BREATH, DRAM, PERSE, CONSENT, and JAIL) and columns (d) through (f) hold constant one or more measure of economic conditions. Column (e) provides the most comprehensive set of regressors. Specification (f) is the same as model (e), except that the year dummy variables are omitted. Discussion of these results is reserved for section 3.2.

The advantage of controlling for fixed-effects is illustrated in columns (a) and (b). When state dummy variables are excluded (specification a), the beer tax coefficient has the "wrong" sign -- taxes are positively and significantly related to predicted traffic fatalities. By contrast, the tax parameter has the expected negative sign when state-effects are accounted for (model b). Conversely, the MLDA coefficient is virtually identical in the two models. The sensitivity of the estimated tax effect to the inclusion of state-specific intercepts was further tested for using a variety of alternative specifications of the VFR equation and also when considering traffic deaths of 18 to 20 year olds. These results (which are not shown) confirm that the tax coefficient is frequently positive and highly sensitive to the choice of regressors when fixed-effects are omitted but significantly negative and relatively robust to these changes in the FE models.

The importance of accounting for simultaneous changes in different types of DUI legislation is revealed by comparing results for specifications (b) and (c). Whereas the beer tax coefficient is virtually unaffected by the addition of the five new alcohol regulations, the predicted MLDA elasticity of traffic mortality declines, in absolute value, by more than $40 \%$ (falling from -0.45 to -0.27 ). This implies that previous investigations overstate the benefits of

young drivers are also usually positive but frequently statistically insignificant. 
raising the minimum legal drinking age to the extent that they fail to account for other types of anti-drunk driving legislation that were being enacted or strengthened at the same time.

Columns (d) and (e) demonstrate the need to also control for macroeconomic conditions. The absolute value of the predicted beer tax elasticity decreases by $30 \%$ (from -0.16 to -0.11 ) when covariates for unemployment and per capita incomes are added (compare columns c and e). The corresponding reduction in the MLDA elasticity exceeds $50 \%$ (falling from -0.27 to -0.13 ) and no longer differs from zero at conventional significance levels. As anticipated, incomes are positively related and unemployment rates negatively associated with traffic deaths.

Notice that both per capita incomes and unemployment rates must be held constant to adequately capture the effects of the macroeconomy. Controlling for incomes alone actually slightly increases the estimated drinking age effect (see column d), whereas also including an unemployment regressor dramatically reduces it (specification e). As discussed in section 2, this occurs because relative rates of joblessness were rising in states that instituted 21 year-old MLDAs during the middle 1980s. Prior studies which do not hold constant unemployment rates are therefore likely to overstate the effects of drinking ages on traffic deaths.

Among the other types of drunk-driving legislation, only dram shop laws are negatively and significantly correlated with traffic deaths in model (e). Even for this class of regulations, however, the parameter estimate is only around one-third as when macroeconomic conditions are ignored (specification c). The coefficients on BREATH, PERSE, and JAIL are never significant, at conventional levels, and are positive more often than negative. The parameter estimate on CONSENT is negative and significant in specification (c) but becomes insignificant in models (d) and (e). ${ }^{16}$

${ }^{16}$ Similar results were obtained in equations estimated without state fixed-effects. Important 
To summarize, previous research is likely to overstate the effect on traffic mortality of raising the minimum drinking age to the extent it does not account for simultaneous changes in other types of anti-drunk driving legislation and macroeconomic conditions. The exclusion of controls for personal incomes and unemployment rates also leads to an exaggerated estimate of the impact of alcohol taxes, although this bias is substantial smaller than for the MLDA. Among the other DUI regulations considered, only dram shop laws have a statistically significant association with the VFR but their estimated impact is dramatically reduced by the inclusion of covariates for economic conditions.

\subsection{Unmeasured Factors}

The alcohol policies controlled for could be correlated with related laws (e.g. anti-plea bargaining statutes, mandatory fines, or sobriety checkpoints) which have not been held constant. These represent possible omitted variables biases. A still more important potential source of confounding is the increased intensity of community efforts to change public attitudes towards drinking and driving. As discussed, the influence of groups such as Mothers Against Drunk Driving, which lobby for strict regulatory policies but also attempt to reduce alcohol-involved driving in other ways (e.g. designated driver programs), grew substantially during the period investigated. To the extent that the legislation proxies these grassroots activities, the econometric estimates will overstate the impact of the laws. Without acquiring detailed data on the local efforts, this source of spurious correlation can not be eliminated; however, some indication of the magnitude of the resulting biases can be obtained.

differences include the aforementioned instability of beer tax coefficients, significant positive coefficients on JAIL and negative parameter estimates for personal incomes. The last two results suggest that states pass mandatory jail/community service laws when concerned about high rates of traffic fatalities and that death rates are high in relatively poor states, possibly due to inferior road conditions or vehicle maintenance. 
State and national legislatures have typically viewed alcohol taxes as a source of budget revenues, rather than as a determinant of drinking behavior. Therefore, it is unlikely that beer taxes are highly correlated with changes in DUI legislation or have been strongly influenced by community efforts to decrease drunk-driving. Indeed, the tax rate has declined in real terms throughout most of the period of intensive grassroots and regulatory activity. By contrast, the drunk-driving laws considered were changing at approximately the same time as other (unmeasured) alcohol-control policies, presumably partially as the result of community campaigns to reduce drunk-driving. Thus, states adopting the most DUI stringent legislation are likely to have been those with the strongest grassroots movements. Legal drinking ages represent a middle ground. They were probably powerfully affected by community activities prior to passage of the Federal Uniform Drinking Act of 1984. Subsequently, states were required to institute a 21 year old MLDA, or else lose a portion of their federal highway funds; hence it is probable that the last states to raise drinking ages may have been those with relatively weak local anti-drunk driving activities.

These arguments suggest that the omitted variables biases resulting from related types of regulations and unmeasured community efforts will be most severe when estimating the effects of anti-DUI legislation but less problematic when considering alcohol taxes. Evidence on the effects of confounding factors for which information is available supports this expectation. As shown in table 3, the predicted MLDA elasticity is dramatically reduced by the addition of the five types of DUI legislation, whereas the estimated impact of beer taxes is much more robust (compare specifications $b$ and $c$ ). The tax estimates are also less sensitive to the inclusion of controls for macroeconomic variables than any of the alcohol regulations. For example, the beer 
tax coefficient falls $29 \%$, between specification (c) and (e), as compared to decreases of $52 \%$, $65 \%$, and $96 \%$ for MLDA, DRAM, and PERSE respectively.

Further information is provided by considering equations which exclude the vector of time effects (model $\mathrm{f}$ ). When year dummy variables are included (specification e), grassroots efforts which are national in scope will be captured as a declining time trend in the individual year intercepts..$^{17}$ Conversely, in column (f), they will be incorporated into the estimated regulatory effects, to the extent that the legislation is correlated with the community activities. Local campaigns which exceed or fall short of national efforts will not be captured by this comparison, however, the remaining heterogeneity bias may be expected to follow the same patterns as the components which we can identify.

If liquor taxes are determined largely independently of non-legislative activities, whereas enactment of DUI regulations is not, as hypothesized, we expect the exclusion of time dummy effects to result in a smaller increase in the estimated beer tax parameters than of those related to alcohol laws. Comparison of the final two columns of table 3 verifies that this occurs. For example, the coefficients on MLDA and PERSE are more than twice as large in specification (f) as in model (e) and the already large coefficient on DRAM increases $86 \%$. By contrast, the absolute value of the beer tax elasticity rises less than $3 \%$.

\subsection{Night-Time and Youth Fatalities}

Table 4 summarizes the results of fixed-effect estimates for the two alternative outcomes -- night-time deaths and fatal accidents involving 18 to 20 year olds. Specifications correspond to those in table 3. Results for the NVFR are similar to those for all traffic deaths. In particular,

${ }^{17}$ Using the estimates in model (e), ceteris paribus vehicle fatality rates are predicted to be $19 \%$ lower in 1988 than in 1982. 
the estimated MLDA elasticity declines dramatically in absolute value (falling from -0.56 to -0.30 ) when the five types of DUI legislation are controlled for (specification c) and becomes a statistically insignificant -0.13 when macroeconomic conditions are also held constant (specification e). The beer tax elasticities are again fairly robust to the addition of covariates and are of somewhat larger size for night-time deaths than for the VFR (-0.18 vs. -0.11 in specification e). Dram shop laws have a stronger predicted negative impact on the NVFR than on total deaths (the coefficient, in model e, is -0.749 for the former versus -0.380 for the latter). Finally, whereas the predicted deterrent effects of the alcohol-control regulations rise substantially with the exclusion of dummy variables (column f), a much smaller increase is observed for beer taxes.

The data reveal five important differences when considering deaths of 18 to 20 year olds. First, the legal drinking age has a substantial and significant negative predicted impact on fatalities in all specifications. For instance, the MLDA elasticity is -0.90 , in model (e), for youths compared to -0.13 for the VFR. Second, the deterrent effect of beer taxes is also somewhat stronger than for the full sample ( -0.17 versus -0.11 in specification $)$. Third, dram shop laws have little or no effect on youth fatalities, probably because 18 to 20 year olds do relatively little of their drinking in bars or restaurants. Fourth, administrative per se laws have stronger predicted deterrent effects than for the full sample. Finally, the impact of raising the MLDA is much more robust to changes in model specifications for this age group than for total deaths. $^{18}$

${ }^{18}$ The econometric models were also separately estimated for traffic deaths involving 15-17 and 21-24 year olds. Among the younger group, the only variable (other than the state and time effects) which is ever statistically significant is the unemployment rate. Similar results are obtained for 21-24 year fatalities as for the VFR. In particular, the MLDA coefficient is negative and significant in specification (b) but becomes small and insignificant in specification (e), 


\subsection{Predicted Effects of Policy Changes}

I next calculate the predicted effects of three policy changes on highway deaths, using alternative model specifications. The policies are: 1) raising the average real beer tax rate from its 1988 level of $\$ 0.437$ per case (in $\$ 1987$ ) to $\$ 0.778$ per case, the rate existing in $1975 ; 2$ ) increasing the MLDA from 18 to 21 in every state; 3 ) adding dram shop legislation in every state. Results of these simulations are displayed on table 5.

In the parsimonious fixed-effect model (specification b), higher drinking ages and beer taxes decrease the predicted vehicle fatality rates by $6 \%$ and $10 \%$ respectively (see the top panel of the table). Adding controls for the five types of DUI legislation (model c) reduces the MLDA impact to $4 \%$ but leaves the tax effect essentially unchanged, with dram shop legislation associated with a $10 \%$ decline in traffic mortality. When economic conditions are also held constant (specification e), the fall in the predicted VFR is $8 \%, 2 \%$, and $4 \%$, respectively, for beer taxes, drinking ages, and dram shop legislation.

The response of night-time fatalities, shown in the middle panel of table 5, to the three policies is similar. In specification (e), changes in alcohol taxes, MLDAs, and dram shop laws reduce the expected NVFR by $12 \%, 2 \%$, and $8 \%$. The MLDA effect is again most sensitive to alternative specifications, declining by three-quarters between models (b) and (e), as compared to a corresponding reduction of less than one-eighth for beer taxes.

Increases in MLDAs and beer taxes both strongly reduce the predicted fatalities of 18 to 20 year olds (see the bottom panel of the table). The decreases are of approximately equal size ( $12 \%$ and $11 \%$ respectively in model e) and are fairly robust to changes in model specifications.

whereas the parameter estimate on beer taxes is only slightly reduced by the addition of controls for alcohol regulations and macroeconomic conditions. 
It is particularly noteworthy that the expected drinking age effect falls by just $20 \%$ (from $15.3 \%$ to $12.2 \%$ ) between specifications (b) and (e), versus a decline of almost $70 \%$ (from $6.3 \%$ to $1.9 \%$ ) for fatalities involving all age groups. Higher alcohol taxes also result in a larger predicted reduction in youth than total deaths, whereas dram shop laws have essentially no impact, once macroeconomic conditions are controlled for.

\section{Conclusion and Implications}

During the last 15 years, many states have enacted or strengthened regulations designed to deter drinking and drunk-driving. Previous research supplies limited and often contradictory information on the effectiveness of these policies in reducing the number of traffic fatalities. By highlighting the fragility of the parameter estimates on key alcohol-control policies to reasonable changes in model specifications, this investigation provides at least a partial explanation for the ambiguous findings .

Special attention is paid to omitted variable biases resulting from the failure to control for simultaneous changes in other types of alcohol legislation and for macroeconomic conditions existing at the time the laws were enacted. For instance, the predicted reduction in vehicle death rates from raising the minimum drinking age from 18 to 21 declines by $70 \%$, and becomes statistically insignificant, with the addition of covariates for per capita incomes, unemployment rates, and five DUI statutes. Indeed, in the most fully specified model, dram shop laws are the only regulatory variable with a statistically significant negative impact on traffic mortality. Even in this case, the estimated coefficients are likely to represent upper bounds of the true impacts because many of the laws were being enacted at the same time as other (not controlled for) legislation and may partially proxy the effects of unmeasured community efforts to combat drunk-driving. ${ }^{19}$ 
This does not imply that all alcohol-control policies are necessarily ineffective. For instance, legal drinking ages are strongly negatively related to the fatalities of 18 to 20 year olds and these estimates appear to be robust to changes in model specifications. Generally, however, future research needs to more carefully control for a comprehensive set of regulatory variables and to account for grassroots activities, such as those by Mothers Against Drunk-Driving, if it is to provide useful information on the independent impact of the different types of DUI legislation.

In contrast to the more fragile results for the regulatory policies, higher beer taxes appear to significantly reduce vehicle deaths and the parameter estimates obtained from fixed-effect models are relatively insensitive to the choice of specifications. That the omitted variable bias is less severe than for regulations is not surprising when considering that alcohol taxes were declining, in real terms, during the period of intensive legislative and social change.

Stricter alcohol laws, unless draconian in nature, are unlikely to yield a significant further decline in traffic fatalities. The United States now has a uniform 21 year old drinking age and most states have already instituted stringent policies designed to deter drunk-driving. By contrast, substantial decreases in vehicle dẹaths probably could be obtained by increasing alcohol tax rates, which remain low by historical standards. For instance, the "preferred" econometric estimates suggest that restoring the real 1988 beer tax to the level prevailing 13 years earlier would have resulted in an $8 \%$ reduction in highway fatalities, saving more than 3700 lives annually.

${ }^{19}$ The policies could, of course, yield benefits other than reductions in traffic deaths. For instance, Cook \& Moore (1993b) document a positive relationship between drinking ages and levels of educational attainment and Mullahy \& Sindelar $(1993,1995)$ uncover a negative association between problem drinking and future incomes or employment. 
Without a full benefit-cost analysis, it is not possible to say whether such a tax increase is desirable. It is worth noting, however, that only a small portion of the tax represents an efficiency cost, with the remainder a transfer of consumer surplus to the government. For instance, with a perfectly elastic supply curve, the estimated deadweight loss is less than two cents per case of beer (in \$1987). ${ }^{20}$ Furthermore, research by Manning, et. al. (1989) suggests that liquor taxes only partially cover the external costs of drinking and Kenkel (1993b) argues that alcohol problems can more efficiently be reduced by raising taxes than by increasing the legal drinking age.

${ }^{20}$ The area of the Harberger triangle is calculated as $(.5 \times .079 \times \$ 0.341 / \mathrm{case})=\$ 0.0134 /$ case. 


\section{References}

Card, David and Alan B. Krueger. 1994. "Minimum Wages and Employment: A Case Study of the Fast-Food Industry in New Jersey and Pennsylvania" American Economic Review, Vol. 84 , No. 4, 772-93.

Chaloupka, Frank J., Henry Saffer, and Michael Grossman. 1993. "Alcohol Control Policies and Motor Vehicle Fatalities" Journal of Legal Studies, Vol. 22, No. 1, 161-86.

Coate, Douglas and Michael Grossman. 1988. "Effects of Alcohol Beverage Prices and Legal Drinking Ages on Youth Alcohol Use" Journal of Law and Economic, Vol. 31, No. 1, 145-72.

Cook, Philip J. and George Tauchen. 1982. "The Effect of Liquor Taxes on Heavy Drinking" Bell Journal of Economics, Vol. 13, No. 4, 379-90.

Cook, Phillip J. and George Tauchen. 1984. "The Effect of Minimum Drinking Age Legislation on Youthful Auto Fatalities, 1970-77" Journal of Legal Studies, Vol. 13, No. 1, 169-90.

Cook, Philip J. and Michael J. Moore. 1993. "Taxation of Alcoholic Beverages" in: Michael Hilton and Gregory Bloss, eds., Economics and the Prevention of Alcohol-Related Problems (U.S. Department of Health and Human Services: Rockville, MD), 33-58. (1993a)

Cook, Phillip J. and Michael J. Moore. 1993. "Drinking and Schooling" Journal of Health Economics, Vol. 12, No. 4, 411-29. (1993b)

DuMouchel William, Allan F. Williams, Paul Zador. 1987. "Raising the Alcohol Purchase Age: Its Effects on Fatal Motor Vehicle Crashes in Twenty-Six States" Journal of Legal Studies, Vol. 26, January, 249-66.

Economic Report of the President. 1992. (U.S. Government Printing Office: Washington, D.C.).

Evans, William and John D. Graham. 1988. "Traffic Safety and the Business Cycle" Alcohol Drugs and Driving, Vol. 4, No. 1, 31-38.

Evans, William N., Doreen Neville, and John D. Graham. 1991. "General Deterrence of Drunk Driving: Evaluation of Recent American Policies" Risk Analysis, Vol. 11, No. 2, 279-89.

Federal Highway Administration. Various Years. Highway Statistics. Washington D.C.: U.S. Government Printing Office.

Gruber, Jonathan. 1994. "The Incidence of Mandated Maternity Benefits" American Economic Review, Vol. 84(3), 622-41. 
Grossman, Michael, Jody L. Sindelar, John Mullahy, and Richard Anderson. 1993. "Alcohol and Cigarette Taxes" Journal of Economic Perspectives, Vol. 7, No. 4, 211-22.

Kenkel, Donald S. 1993. "Drinking, Driving, and Deterrence: The Effectiveness and Social Costs of Alternative Policies" Journal of Law and Economics, Vol. 36, October, 877-913. (1993a)

Kenkel, Donald S. 1993. "Prohibition Versus Taxation: Reconsidering the Legal Drinking Age" Contemporary Policy Issues, Vol. 11, No. 3, 48-57. (1993b)

Manning, Willard G., Emmett B. Keeler, Joseph P. Newhouse, Elizabeth M. Sloss, Jeffrey Wasserman. 1989. "The Taxes of Sin: Do Smokers and Drinkers Pay Their Way?" Journal of the American Medical Association, Vol. 261, No. 11, 1604-9.

Manning, Willard G., Linda Blumberg, and Lawrence H. Moulton. Forthcoming. The Demand for Alcohol: The Differential Response to Price, Journal of Health Economics.

Mullahy, John and Jody L. Sindelar. 1993. "Alcoholism, Work, and Income" Journal of Labor Economics, Vol. 11, No. 3, 494-520.

Mullahy, John and Jody L. Sindelar. 1995. "Employment, Unemployment, and Problem Drinking", NBER Working Paper, No. 5123.

O'Malley, Patrick M. and Alexander C. Wagenaar. 1991. "Effects of Minimum Drinking Age Laws on Alcohol Use, Related Behaviors, and Traffic Crash Involvement among American Youth: 1976-1987" Journal of Studies on Alcohol, Vol. 52, No. 5, 478-91.

Pogue, Thomas F. and Larry G. Sgontz. 1989. "Taxing to Control Social Costs: The Case of Alcohol" American Economic Review, Vol. 79, No. 1, 235-43.

Ruhm, Christopher J. Forthcoming. "Economic Conditions and Alcohol Problems" Journal of Health Economics.

Saffer, Henry and Frank Chaloupka. 1989. "Breath Testing and Highway Fatality Rates" Applied Economics, Vol. 21, 901-12.

Saffer, Henry and Michael Grossman. 1987. "Drinking Age Laws and Highway Mortality Rates: Cause and Effect" Economic Inquiry, Vol. 25, July, 403-17. (1987a)

Saffer, Henry and Michael Grossman. 1987. "Beer Taxes, The Legal Drinking Age, and Youth Motor Vehicle Fatalities" Journal of Legal Studies, Vol. 16, June, 351-74. (1987b)

Sloan, Frank A. and Penny B. Githens. 1994. "Drinking, Driving, and the Price of Automobile Insurance" The Journal of Risk and Insurance, Vol. 61, No. 1, 33-58. 
Sloan, Frank A., Bridget A. Reilly, and Christopher M. Schenzler. 1994. "Tort Liability Versus Other Approaches for Deterring Careless Driving" International Review of Law and Economics, Vol. 14, 53-71.

Sloan, Frank A., Bridget A. Reilly, and Christopher M. Schenzler. Forthcoming. "Effects of Tort Liability and Insurance on Heavy Drinking and Drinking and Driving" Journal of Law and Economics.

U.S. Brewers' Association. Various Years. The Brewer's Almanac. Washington D.C.: U.S. Brewers' Association.

U.S. Department of Commerce. 1989. State Personal Income: 1929-87. Washington D.C.: U.S. Government Printing Office.

U.S. Department of Commerce. 1990. Statistical Abstract of the United States: 1990. Washington D.C.: U.S. Government Printing Office.

U.S. Department of Transportation, National Highway Traffic Safety Administration. Various Years. A Digest of State Alcohol-Highway Safety Laws. Washington D.C.: U.S. Government Printing Office.

Wagenaar, Alexander C. 1993. "Minimum Drinking Age and Alcohol Availability to Youth: Issues and Research Needs" in: Michael Hilton and Gregory Bloss, eds., Economics and the Prevention of Alcohol-Related Problems (U.S. Department of Health and Human Services: Rockville, MD), 175-200.

Wagenaar, Alexander C. 1991/2. "Legal Minimum Drinking Age Changes in the United States: 1970-81" Alcohol Health and Research World, Winter, pp. 21-26.

Wagenaar, Alexander C. and Richard G. Maybee. 1986. "The Legal Minimum Drinking Age in Texas: Effects of An Increase from 18 to 19" Journal of Safety Research, Vol. 17, No. 4, Winter, 165-78.

Wilkinson, James T. 1987. "Reducing Drunken Driving: Which Policies are Most Effective" Southern Economic Journal, Vol. 54, No. 2, 322-34.

Zobeck, Terry S., Frederick S. Stinson, Bridget F. Grant, and Darryl Bertolucci. 1993. Trends in Alcohol-Related Fatal Traffic Crashes, United States: 1979-91, Washington, D.C.: National Institute of Alcohol Abuse and Alcoholism, Surveillance Report \#26, November. 


\begin{tabular}{|c|c|c|c|}
\hline \multicolumn{4}{|c|}{$\begin{array}{c}\text { Table 1: } \\
\text { Results of Previous Research On Drinking and Motor Vehicle Fatalities }\end{array}$} \\
\hline Author & Sample & Important Results & Comments \\
\hline $\begin{array}{l}\text { Chaloupka, } \\
\text { Saffer, \& } \\
\text { Grossman } \\
(1993)\end{array}$ & $\begin{array}{l}\text { State level data } \\
\text { for 1982-88 } \\
\text { obtained from } \\
\text { the Fatal } \\
\text { Accident } \\
\text { Reporting } \\
\text { System (FARS) } \\
\text { and other } \\
\text { sources. }\end{array}$ & $\begin{array}{l}\text { Vehicle fatality rate (VFR) reduced by } \\
\text { preliminary breath test, administrative } \\
\text { per se, dram shop, anti-plea bargaining, } \\
\text { and implied consent laws, as well as } \\
\text { beer taxes and (sometimes) minimum } \\
\text { legal drinking ages (MLDAs). Weaker } \\
\text { deterrent effects for mandatory fines } \\
\text { and licence sanctions. No effect of } \\
\text { mandatory jail sentences, open } \\
\text { container, or illegal per se laws. }\end{array}$ & $\begin{array}{l}\text { Estimates include controls for } \\
\text { per capita incomes, state } \\
\text { unemployment rates, year } \\
\text { effects, and a wide variety of } \\
\text { demographic characteristics } \\
\text { but not state fixed effects. }\end{array}$ \\
\hline $\begin{array}{l}\text { Cook \& } \\
\text { Tauchen } \\
(1984)\end{array}$ & $\begin{array}{l}\text { State level data } \\
\text { for } 1970-77 \text { from } \\
\text { the National } \\
\text { Underlying } \\
\text { Cause of Death } \\
\text { Microdata tapes } \\
\text { \& other sources. }\end{array}$ & $\begin{array}{l}\text { MLDAs negatively related to youth } \\
\text { VFR but unrelated to fatality rates of } \\
21-24 \text { year olds. }\end{array}$ & $\begin{array}{l}\text { Year and state effects } \\
\text { controlled for. No controls } \\
\text { for alcohol prices or policies } \\
\text { or economic conditions. }\end{array}$ \\
\hline $\begin{array}{l}\text { DuMouchel, } \\
\text { Williams, \& } \\
\text { Zador }(1987)\end{array}$ & $\begin{array}{l}\text { State level data } \\
\text { for } 1975-84 \text { from } \\
\text { FARS \& other } \\
\text { sources. }\end{array}$ & $\begin{array}{l}\text { MLDAs negatively correlated with } \\
\text { night VFR. (Effects calculated by } \\
\text { comparing changes for persons under } \\
\text { vs. those over the legal drinking age). }\end{array}$ & $\begin{array}{l}\text { State effects included; no } \\
\text { controls for alcohol prices or } \\
\text { policies or for economic } \\
\text { conditions. }\end{array}$ \\
\hline $\begin{array}{l}\text { Evans, } \\
\text { Neville, \& } \\
\text { Graham } \\
(1991)\end{array}$ & $\begin{array}{l}\text { State level data } \\
\text { for } 1975-86 \\
\text { obtained from } \\
\text { various sources. }\end{array}$ & $\begin{array}{l}\text { VFR reduced by higher alcohol taxes, } \\
\text { sobriety checkpoints, mandatory seat } \\
\text { belt, open container, and administrative } \\
\text { per se laws. No effect of anti-plea } \\
\text { bargaining statutes, mandatory jail } \\
\text { terms. Illegal per se and preliminary } \\
\text { breath test laws may have some effect } \\
\text { when used in conjunction with sobriety } \\
\text { checkpoints. }\end{array}$ & $\begin{array}{l}\text { State effects, time effects, } \\
\text { and unemployment rates } \\
\text { controlled for; MLDAs and } \\
\text { personal incomes are not. }\end{array}$ \\
\hline $\begin{array}{l}\text { Kenkel } \\
(1993 a)\end{array}$ & $\begin{array}{l}\text { Health Promo- } \\
\text { tion \& Disease } \\
\text { Supplement to } \\
\text { the } 1985 \text { Health } \\
\text { Interview Survey } \\
\text { \& other sources. } \\
\end{array}$ & $\begin{array}{l}\text { Alcohol prices and MLDAs negatively } \\
\text { related to drunk-driving. Mandatory } \\
\text { jail terms, sobriety breath tests, and } \\
\text { anti-plea bargaining laws reduce DUI. } \\
\text { Mixed effects for preliminary breath } \\
\text { test and administrative per se statutes. }\end{array}$ & $\begin{array}{l}\text { Information on drinking \& } \\
\text { driving only obtained for one } \\
\text { point in time. No controls for } \\
\text { state effects. Income and } \\
\text { employment status are } \\
\text { controlled for. }\end{array}$ \\
\hline $\begin{array}{l}\text { O'Malley \& } \\
\text { Wagenaar } \\
(1991)\end{array}$ & $\begin{array}{l}\text { Monitoring the } \\
\text { Future Surveys } \\
1976-87, \text { FARS } \\
\text { data } 1976-86 .\end{array}$ & $\begin{array}{l}\text { MLDA's negatively related to alcohol } \\
\text { consumption of teenagers and young } \\
\text { adults and to VFR of youths under } 21 \\
\text { years old. }\end{array}$ & $\begin{array}{l}\text { Analysis does not account for } \\
\text { trends in states not changing } \\
\text { MLDA. No controls for } \\
\text { alcohol prices, policies or } \\
\text { economic conditions. }\end{array}$ \\
\hline & & ) & \\
\hline
\end{tabular}




\begin{tabular}{|c|c|c|c|}
\hline $\begin{array}{l}\text { Saffer \& } \\
\text { Chaloupka } \\
(1989)\end{array}$ & $\begin{array}{l}\text { State level data } \\
\text { for } 1980-85 \text { from } \\
\text { FARS and other } \\
\text { sources. }\end{array}$ & $\begin{array}{l}\text { Preliminary breath test laws reduce } \\
\text { VFR, particularly night-time fatalities. } \\
\text { Higher beer taxes and MLDAs } \\
\text { negatively related to all types of VFR. }\end{array}$ & $\begin{array}{l}\text { Time effects, unemployment } \\
\text { rates, and incomes sometimes } \\
\text { controlled for. Other alcohol } \\
\text { control policies not included. }\end{array}$ \\
\hline $\begin{array}{l}\text { Saffer \& } \\
\text { Grossman } \\
(1987 a, b)\end{array}$ & $\begin{array}{l}\text { State level data } \\
\text { for } 1975-81 \text { from } \\
\text { FARS and other } \\
\text { sources. }\end{array}$ & $\begin{array}{l}\text { Beer taxes and MLDA's negatively } \\
\text { related to VFR. MLDA effect } \\
\text { strengthened when state and time } \\
\text { effects are added. Two-stage } \\
\text { procedure used to test for potential } \\
\text { endogeneity of MLDA (in 1987a). }\end{array}$ & $\begin{array}{l}\text { Per capita incomes controlled } \\
\text { for but unemployment rates } \\
\text { are not. In two-stage stage } \\
\text { model, identification relies on } \\
\text { nonlinearities. }\end{array}$ \\
\hline $\begin{array}{l}\text { Sloan \& } \\
\text { Githens } \\
(1994)\end{array}$ & $\begin{array}{l}\text { Behavioral Risk } \\
\text { Factor Survey, } \\
1989, \text { and other } \\
\text { sources. }\end{array}$ & $\begin{array}{l}\text { Mandatory jail terms and higher } \\
\text { insurance premiums for DUI reduce } \\
\text { probability and frequency of drinking } \\
\text { and driving. No significant effect of } \\
\text { fines or license revokation. }\end{array}$ & $\begin{array}{l}\text { Data available for only a } \\
\text { single cross-section. Family } \\
\text { incomes controlled for but } \\
\text { unemployment rates and } \\
\text { alcohol prices are not. }\end{array}$ \\
\hline $\begin{array}{l}\text { Sloan, } \\
\text { Reilly, \& } \\
\text { Schenzler } \\
(1994)\end{array}$ & $\begin{array}{l}\text { State level data, } \\
\text { 1980-92, from } \\
\text { FARS and other } \\
\text { sources. }\end{array}$ & $\begin{array}{l}\text { VFR reduced by dram shop laws, } \\
\text { mandatory jail sentences, higher } \\
\text { MLDAs and (for some groups) alcohol } \\
\text { prices. Mixed effects of insurance } \\
\text { regulations (no fault, alternative } \\
\text { negligence rules) and administrative } \\
\text { per se laws. Some results sensitive to } \\
\text { inclusion of time dummy variables. }\end{array}$ & $\begin{array}{l}\text { State and year effects } \\
\text { controlled for but } \\
\text { unemployment rates are not. }\end{array}$ \\
\hline $\begin{array}{l}\text { Sloan, } \\
\text { Reilly, \& } \\
\text { Schenzler } \\
\text { (forth- } \\
\text { coming) }\end{array}$ & $\begin{array}{l}\text { Behavioral Risk } \\
\text { Factor Surveys, } \\
\text { 1984-90, and } \\
\text { other sources. }\end{array}$ & $\begin{array}{l}\text { Alcohol prices, MLDAs, tort liability } \\
\text { rules (contributory vs. comparative } \\
\text { negligence, traditional vs. no-fault), } \\
\text { and compulsory liability insurance } \\
\text { reduce binge drinking and DUI. No } \\
\text { effect for fines, dram shop, or } \\
\text { administrative per se laws. Weak } \\
\text { effects of mandatory jail terms. }\end{array}$ & $\begin{array}{l}\text { Time trend and family } \\
\text { incomes controlled for but } \\
\text { state effects and } \\
\text { unemployment rates are not. }\end{array}$ \\
\hline $\begin{array}{l}\text { Wagenaar \& } \\
\text { Maybee } \\
(1986)\end{array}$ & $\begin{array}{l}\text { State level data } \\
\text { on traffic crashes } \\
\text { for } 1978-84 \text { in } \\
\text { Texas. Source } \\
\text { not stated. }\end{array}$ & $\begin{array}{l}\text { Raising the MLDA from } 18 \text { to } 19 \\
\text { reduces single vehicle night-time } \\
\text { crashes of drivers } 18 \text { and under. }\end{array}$ & $\begin{array}{l}\text { National trends in drunk } \\
\text { driving, demographic } \\
\text { characteristics, alcohol prices } \\
\text { or regulations not controlled } \\
\text { for. Unemployment rates or } \\
\text { industrial index of production } \\
\text { proxy economic conditions. }\end{array}$ \\
\hline $\begin{array}{l}\text { Wilkinson } \\
\text { (1987) }\end{array}$ & $\begin{array}{l}\text { State level data, } \\
1976-80 \text { from } \\
\text { various sources. }\end{array}$ & $\begin{array}{l}\text { Higher MLDA or alcohol prices } \\
\text { reducing drinking and VFR; no } \\
\text { statistically significant effect of any } \\
\text { deterrence variables (arrest \& } \\
\text { conviction probabilities for DUI, } \\
\text { expected fines, or mandatory jail } \\
\text { sentences). }\end{array}$ & $\begin{array}{l}\text { No controls for state or time } \\
\text { effects. Personal incomes } \\
\text { controlled for but } \\
\text { unemployment rates are not. }\end{array}$ \\
\hline
\end{tabular}


Table 2: Time Trends in Alcohol Taxes and Regulations

\begin{tabular}{|c|c|c|c|c|c|c|c|}
\hline \multirow[b]{2}{*}{ Year } & \multirow{2}{*}{$\begin{array}{c}\text { Average } \\
\text { Beer Tax } \\
\text { Rate } \\
\text { (\$1987) }\end{array}$} & \multirow{2}{*}{$\begin{array}{c}\text { Average } \\
\text { Minimum } \\
\text { Legal } \\
\text { Drinking Age } \\
\text { (in years) }\end{array}$} & \multicolumn{5}{|c|}{ Number of States With Specified Alcohol-Control Policy } \\
\hline & & & $\begin{array}{c}\text { Preliminary } \\
\text { Breath Test } \\
\text { Law }\end{array}$ & $\begin{array}{c}\text { Dram Shop } \\
\text { Law }\end{array}$ & $\begin{array}{l}\text { Administrative } \\
\text { Per Se Law }\end{array}$ & $\begin{array}{c}\text { Implied } \\
\text { Consent Law }\end{array}$ & $\begin{array}{c}\text { Mandatory } \\
\text { Jail/Commun- } \\
\text { ity Service }\end{array}$ \\
\hline 1982 & $\$ 0.492$ & 20.09 & 18 & 28 & 4 & 32 & 11 \\
\hline 1983 & $\$ 0.490$ & 20.17 & 22 & 30 & 13 & 34 & 15 \\
\hline 1984 & $\$ 0.483$ & 20.21 & 22 & 31 & 18 & 35 & 16 \\
\hline 1985 & $\$ 0.474$ & 20.38 & 22 & 31 & 19 & 35 & 17 \\
\hline 1986 & $\$ 0.465$ & 20.73 & 23 & 33 & 20 & 35 & 17 \\
\hline 1987 & $\$ 0.452$ & 20.98 & 24 & 35 & 21 & 35 & 16 \\
\hline 1988 & $\$ 0.437$ & 21.00 & 24 & 36 & 22 & 36 & 16 \\
\hline
\end{tabular}

Notes: Data are for the 48 contiguous states. The average minimum legal drinking age and beer tax are weighted by the population in each state. Drinking ages account for "grandfather" clauses and the timing of changes in drinking ages occurring within calendar years. 
Table 3:

Econometric Estimates of Total Vehicle Fatality Equations

Regressor

\section{Specification}

\begin{tabular}{|c|c|c|c|c|c|c|}
\hline & (a) & (b) & (c) & (d) & (e) & (f) \\
\hline Beer Tax & $\begin{array}{l}.1245 \\
(5.88) \\
{[0.06]}\end{array}$ & $\begin{array}{l}-.3235 \\
(3.99) \\
{[0.15]}\end{array}$ & $\begin{array}{c}-.3406 \\
(4.32) \\
{[0.16]}\end{array}$ & $\begin{array}{r}-.2717 \\
(3.77) \\
{[0.13]}\end{array}$ & $\begin{array}{c}-.2414 \\
(3.78) \\
{[0.11]}\end{array}$ & $\begin{array}{r}-.2484 \\
(3.51) \\
{[0.12]}\end{array}$ \\
\hline $\begin{array}{l}\text { Minimum Legal } \\
\text { Drinking Age }\end{array}$ & $\begin{array}{l}-.0238 \\
(1.81) \\
{[0.49]}\end{array}$ & $\begin{array}{l}-.0219 \\
(2.78) \\
{[0.45]}\end{array}$ & $\begin{array}{c}-.0129 \\
(1.61) \\
{[0.27]}\end{array}$ & $\begin{array}{r}-.0145 \\
(1.99) \\
{[0.30]}\end{array}$ & $\begin{array}{c}-.0062 \\
(0.96) \\
{[0.13]}\end{array}$ & $\begin{array}{r}-.0136 \\
(1.99) \\
{[0.28]}\end{array}$ \\
\hline $\begin{array}{l}\text { Preliminary Breath } \\
\text { Test Law }\end{array}$ & & & $\begin{array}{l}.0056 \\
(0.24)\end{array}$ & $\begin{array}{l}.0123 \\
(0.59)\end{array}$ & $\begin{array}{l}.0249 \\
(1.33)\end{array}$ & $\begin{array}{c}-4.1 \mathrm{E}-4 \\
(0.02)\end{array}$ \\
\hline Dram Shop Law & & & $\begin{array}{l}-.1088 \\
(4.93)\end{array}$ & $\begin{array}{l}-.0608 \\
(2.90)\end{array}$ & $\begin{array}{l}-.0380 \\
(2.03)\end{array}$ & $\begin{array}{l}-.0706 \\
(3.48)\end{array}$ \\
\hline $\begin{array}{l}\text { Administrative Per } \\
\text { Se Law }\end{array}$ & & & $\begin{array}{r}-.0224 \\
(1.13)\end{array}$ & $\begin{array}{r}-.0019 \\
(0.11)\end{array}$ & $\begin{array}{l}-.0010 \\
(0.06)\end{array}$ & $\begin{array}{r}-.0295 \\
(1.69)\end{array}$ \\
\hline $\begin{array}{l}\text { Implied Consent } \\
\text { Law }\end{array}$ & & & $\begin{array}{r}-.0935 \\
(1.96)\end{array}$ & $\begin{array}{c}-.0398 \\
(0.91)\end{array}$ & $\begin{array}{l}.0102 \\
(0.26)\end{array}$ & $\begin{array}{r}-.0360 \\
(0.83)\end{array}$ \\
\hline $\begin{array}{l}\text { Mandatory Jail/ } \\
\text { Community Service }\end{array}$ & & & $\begin{array}{l}.0164 \\
(0.59)\end{array}$ & $\begin{array}{l}.0016 \\
(0.06)\end{array}$ & $\begin{array}{l}.0097 \\
(0.43)\end{array}$ & $\begin{array}{r}-.0023 \\
(0.09)\end{array}$ \\
\hline $\begin{array}{l}\text { Personal Income (in } \\
1000 \text { 's) }\end{array}$ & & & & $\begin{array}{l}.0710 \\
(7.74) \\
{[1.05]}\end{array}$ & $\begin{array}{l}.0349 \\
(3.83) \\
{[0.51]}\end{array}$ & $\begin{array}{l}.0144 \\
(1.62) \\
{[0.21]}\end{array}$ \\
\hline Unemployment Rate & & & & & $\begin{array}{c}-.0336 \\
(8.72) \\
{[0.25]}\end{array}$ & $\begin{array}{r}-.0210 \\
(5.54) \\
{[0.16]}\end{array}$ \\
\hline Time Effects & Yes & Yes & Yes & Yes & Yes & No \\
\hline State Fixed-Effects & No & Yes & Yes & Yes & Yes & Yes \\
\hline
\end{tabular}


Note: Table shows results of the grouped data logit model $\ln \left(\frac{p_{i}}{1-r_{i}}\right)=X_{i} \beta+Z_{i \gamma} \gamma+\mu_{i}$, estimated by weighted least squares. Pooled data are used for the 48 contiguous states over the period 1982 through $1988(\mathrm{n}=336)$. All equations also control for the percentage of the state population living in "dry counties", the average number of vehicle miles per person aged 16 and over, and the percent of drivers who are "young" (15-24 years old). Absolute value of $t$ statistics are shown in parentheses. Absolute value of estimated elasticities are shown in brackets. Elasticities are calculated as $\varepsilon_{j}^{*}=(1-\bar{v}) \hat{\beta}_{j} \bar{X}_{j}$, where $\hat{\beta}_{j}$ is the logit coefficient of the jhth regressor and $\bar{X}_{j}$ and $\bar{v}$ are the sample means of the explanatory variable and the motor vehicle fatality rate respectively. 


\begin{tabular}{|c|c|c|c|c|c|c|c|c|}
\hline \multirow{2}{*}{ Regressor } & \multicolumn{4}{|c|}{ Night-time Fatalities } & \multicolumn{4}{|c|}{ Vehicle Fatalities of 18-20 Year Olds } \\
\hline & (b) & (c) & (e) & (f) & (b) & (c) & (e) & (f) \\
\hline Beer Tax & $\begin{array}{l}-.4364 \\
(3.41) \\
{[0.21]}\end{array}$ & $\begin{array}{l}-.4489 \\
(3.49) \\
{[0.21]}\end{array}$ & $\begin{array}{l}-.3808 \\
(3.05) \\
{[0.18]}\end{array}$ & $\begin{array}{l}-.4397 \\
(3.15) \\
{[0.21]}\end{array}$ & $\begin{array}{l}-.4231 \\
(3.12) \\
{[0.20]}\end{array}$ & $\begin{array}{l}-.4258 \\
(3.11) \\
{[0.20]}\end{array}$ & $\begin{array}{c}-.3462 \\
(2.62) \\
{[0.17]}\end{array}$ & $\begin{array}{c}-.4398 \\
(3.04) \\
{[0.21]}\end{array}$ \\
\hline Minimum Legal Drinking Age & $\begin{array}{l}-.0271 \\
(2.31) \\
{[0.56]}\end{array}$ & $\begin{array}{l}-.0145 \\
(1.16) \\
{[0.30]}\end{array}$ & $\begin{array}{c}-.0063 \\
(0.52) \\
{[0.13]}\end{array}$ & $\begin{array}{l}-.0146 \\
(1.12) \\
{[0.30]}\end{array}$ & $\begin{array}{l}-.0552 \\
(4.27) \\
{[1.13]}\end{array}$ & $\begin{array}{l}-.0514 \\
(3.74) \\
{[1.05]}\end{array}$ & $\begin{array}{l}-.0441 \\
(3.33) \\
{[0.90]}\end{array}$ & $\begin{array}{l}-.0412 \\
(3.00) \\
{[0.84]}\end{array}$ \\
\hline Preliminary Breath Test Law & & $\begin{array}{l}.0289 \\
(1.16)\end{array}$ & $\begin{array}{l}.0431 \\
(1.24)\end{array}$ & $\begin{array}{l}.0117 \\
(0.31)\end{array}$ & & $\begin{array}{l}.0331 \\
(0.86)\end{array}$ & $\begin{array}{l}.0522 \\
(1.41)\end{array}$ & $\begin{array}{l}.0538 \\
(1.37)\end{array}$ \\
\hline Dram Shop Law & & $\begin{array}{l}-.1141 \\
(3.34)\end{array}$ & $\begin{array}{l}-.0749 \\
(2.15)\end{array}$ & $\begin{array}{l}-.1218 \\
(3.20)\end{array}$ & & $\begin{array}{r}-.0589 \\
(1.58)\end{array}$ & $\begin{array}{l}-.0082 \\
(0.22)\end{array}$ & $\begin{array}{l}-.0182 \\
(0.45)\end{array}$ \\
\hline Administrative Per Se Law & & $\begin{array}{r}-.0338 \\
(1.12)\end{array}$ & $\begin{array}{r}-.0262 \\
(0.90)\end{array}$ & $\begin{array}{l}-.0791 \\
(2.45)\end{array}$ & & $\begin{array}{l}-.0676 \\
(2.06)\end{array}$ & $\begin{array}{l}-.0556 \\
(1.76)\end{array}$ & $\begin{array}{l}-.0929 \\
(2.72)\end{array}$ \\
\hline Implied Consent Law & & $\begin{array}{l}-.0356 \\
(0.49)\end{array}$ & $\begin{array}{l}.0349 \\
(0.49)\end{array}$ & $\begin{array}{l}-.0515 \\
(0.64)\end{array}$ & & $\begin{array}{l}-.0761 \\
(0.98)\end{array}$ & $\begin{array}{l}.0122 \\
(0.16)\end{array}$ & $\begin{array}{l}-.0418 \\
(0.50)\end{array}$ \\
\hline $\begin{array}{l}\text { Mandatory Jail/Community } \\
\text { Service }\end{array}$ & & $\begin{array}{l}-.0006 \\
(0.02) \\
\end{array}$ & $\begin{array}{l}.0024 \\
(0.06)\end{array}$ & $\begin{array}{l}-.0339 \\
(0.77) \\
\end{array}$ & & $\begin{array}{l}.0112 \\
(0.24)\end{array}$ & $\begin{array}{l}.0099 \\
(0.22) \\
\end{array}$ & $\begin{array}{r}-.0407 \\
(0.86) \\
\end{array}$ \\
\hline Macroeconomic Variables & No & No & Yes & Yes & No & No & Yes & Yes \\
\hline Time Effects & Yes & Yes & Yes & No & Yes & Yes & Yes & No \\
\hline
\end{tabular}


Note: See note on table 3. All equations include state dummy variables and covariates for average vehicle miles, the percentage of young drivers, the percentage of the population living in "dry" counties. Specifications (b) through (e) also include a vector of year dummy variables and models (e) and (f) control for personal incomes and state unemployment rates. Night-time fatalities occur between 12:00 and 3:59 A.M. 


\section{Specification}

\section{Policy Change}

(b)

(c)

(e)

\section{Change in Total Vehicle Fatalities}

Higher Beer Tax

Higher Legal Drinking Age

Imposition of Dram Shop Law
$-10.4 \%$

$-6.3$
$-11.0 \%$

$-3.8$

$-10.3$
$-7.9 \%$

$-1.9$

$-3.7$

Change in Night-Time Fatalities

Higher Beer Tax

Higher Legal Drinking Age

Imposition of Dram Shop Law
$-13.8 \%$

$-7.8$
$-14.2 \%$

$-4.3$

$-10.8$
$-12.2 \%$

$-7.2$

Change in Vehicle Fatalities of 18 to 20 Year Olds
Higher Beer Tax
$-13.4 \%$
$-13.5 \%$
$-11.1 \%$
Higher Legal Drinking Age
$-15.3$
$-14.3$
$-12.2$
Imposition of Dram Shop Law
$-5.7$
$-0.8$

Note: Model specifications are as described in table 3. The following policy changes are considered: 1) an increase in the real beer tax from its 1988 level of $\$ 0.437 /$ case (in $\$ 1987$ ) to the 1975 level of $\$ 0.778$ /case; 2) raising the minimum drinking age from 18 to 21 years old in every state; 3 ) imposition of a dram shop law in every state. 
Table A.1:

Description and Sample Means of Variables Used in Analysis

Variable Description and Source

\section{Outcome Variables: Vehicle Fatality Rates Per 10,000 Persons \\ (Source: Fatal Accident Reporting System)}

Total Vehicle Fatality Rate

Night-time Vehicle Fatality Rate (12:00 - 3:59 A.M)

Total Vehicle Fatality Rate: $18-20$ year olds

\section{Explanatory Variables}

Tax (in \$1987) on 24-12 oz. containers of beer (Source: Brewers Almanac)

Minimum Legal Drinking Age in Years (Source: Wagenaar 1981/2; A Digest of

State-Alcohol Safety Related Legislation)

$\%$ Living in "Dry" Counties (Source: Brewers Almanac)

$4.52 \%$

$\%$ of Licensed Drivers Aged 24 and Younger (Source: Highway Statistics)

$18.0 \%$

Average Miles Driven Per Person Aged 16 and Over (Source: Highway Statistics)

Civilian Unemployment Rate (Source: Unpublished $B L S$ data)

Per Capita Income in $\$ 1987$ (Source: State Personal Income: 1929-87,

Statistical Abstract of the United States: 1990)

Driving-Related Legislation (Source: A Digest of State-Alcohol Safety Related Legislation)

BREATH: police authorized to administer prearrest breath test for alcohol

$42.7 \%$

DRAM: statute or case law authorizing parties injured by intoxicated driver to file a

$67.4 \%$ lawsuit against the alcohol server

PERSE: state licensing agency required to suspend or revoke driver's license after arrest for DUI

CONSENT: law requiring licence sanction for refusing to submit to alcohol

$22.4 \%$ testing

$62.6 \%$

JAIL: law requiring jail sentence or community service for first DUI conviction

Note: Data are for the 48 contiguous states over the period 1982-1988 $(n=336)$. Means are weighted by the noninstitutionalized population aged 16 and over in each state. 
Fig. 1: Time Trends in Selected Variables, 1975-1988

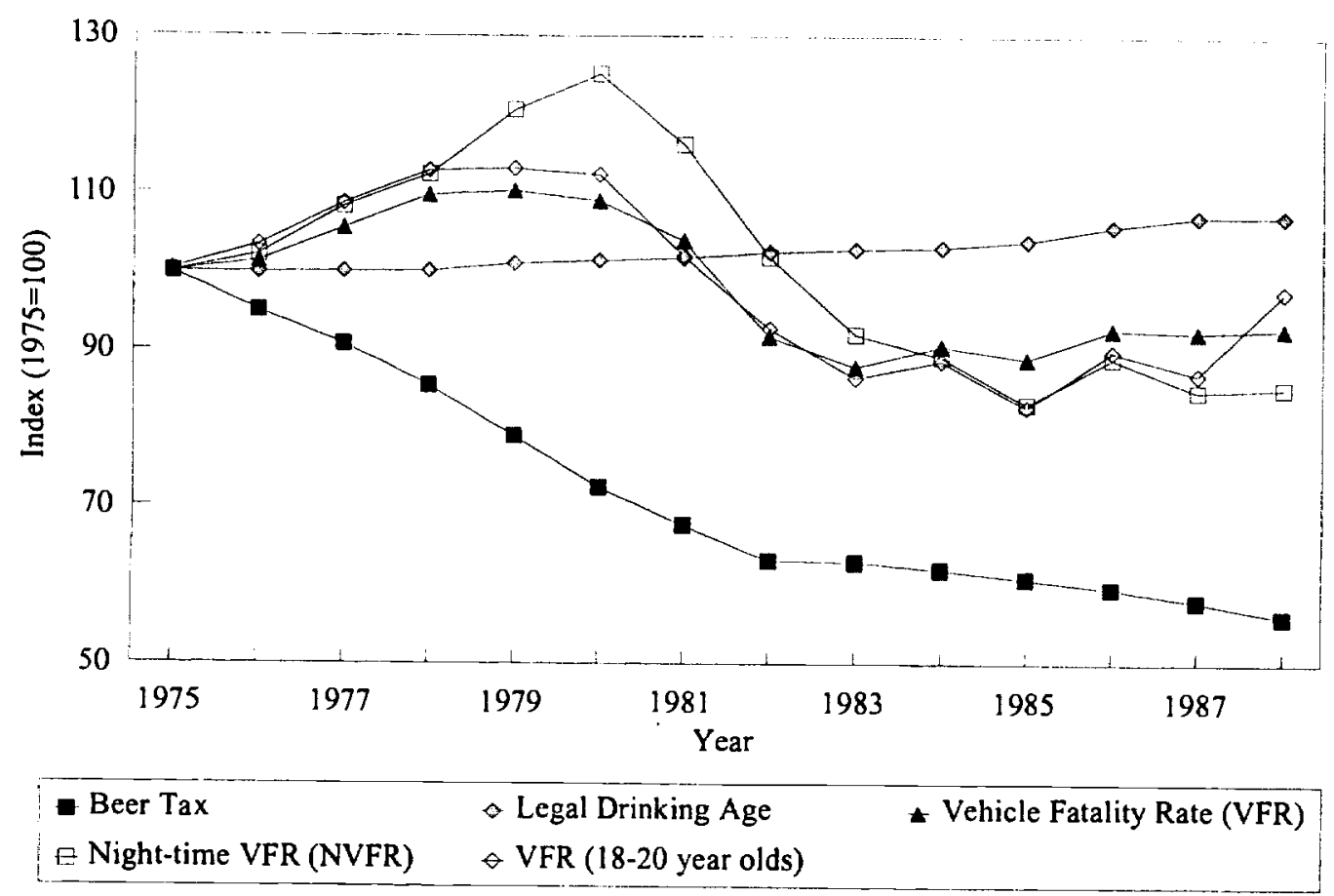

Fig. 2: Average Unemployment Rate in Various Years as a Function

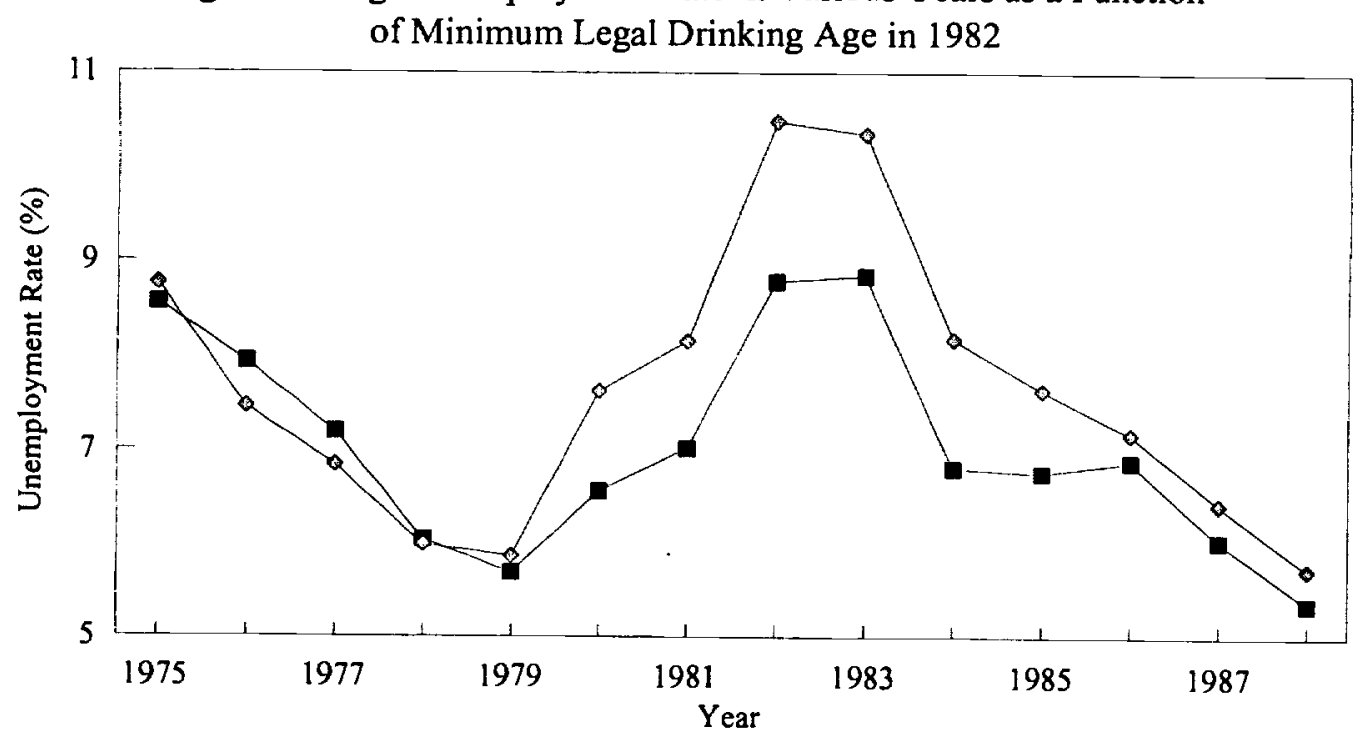

Legal Drinking Age (in 1982) <21 $\approx$ Legal Drinking Age (in 1982) $=21$ 